\title{
ENSAIOS PARA IDENTIFICAÇÃO DE BIOMARCADORES DE EXPOSIÇÃO ÀS RADIAÇÕ ES IONIZANTES
}

\author{
Mariana Brayner Cavalcanti Freire Bezerra ${ }^{1 *}$ \\ ${ }^{1}$ Departamento de Energia Nuclear, CTG, UFPE \\ *maribrayner@yahoo.com.br
}

\section{RESUMO}

A correlação entre a exposição à radiação ionizante e os efeitos biológicos induzidos no homem foi estabelecida, inicialmente, pela observação de efeitos danosos em pessoas nas primeiras exposições aos raios $\mathrm{X}$. Atualmente, os efeitos radioinduzidos são alvos de grandes pesquisas científicas que visam buscar o entendimento de sua origem e de biomarcadores que permitam identificar pessoas expostas às radiações e/ou radiossensíveis. Neste sentido, diversos tipos de células, de genes, de proteínas, de moléculas, de metabó licos são objetos de investigação que podem ser identificados e/ou quantificados por métodos já bem estabelecidos pela comunidade científica. A identificação e/ou a quantificação de biomarcadores também são de grande importância para a avaliação da variabilidade na resposta individual às radiações- ou seja, os diferentes graus de radiossensibilidade - por ser reconhecidamente um aspecto importante para a eficácia da radioterapia. Portanto, há um esforço internacional pela busca de novos biomarcadores e de testes preditivos das reações adversas exacerbadas oriundas da interação da radiação ionizantes com o tecido vivo. 